Portland State University

PDXScholar

$1-12-1976$

\title{
The Androgenic Glands of the Pacific Crayfish, Pacifastacus leniusculus trowbridgii Stimpson, 1859
}

\author{
Larry L. Sanders \\ Portland State University
}

Follow this and additional works at: https://pdxscholar.library.pdx.edu/open_access_etds

Part of the Biology Commons

Let us know how access to this document benefits you.

\section{Recommended Citation}

Sanders, Larry L., "The Androgenic Glands of the Pacific Crayfish, Pacifastacus leniusculus trowbridgii Stimpson, 1859" (1976). Dissertations and Theses. Paper 2390.

https://doi.org/10.15760/etd.2387

This Thesis is brought to you for free and open access. It has been accepted for inclusion in Dissertations and Theses by an authorized administrator of PDXScholar. Please contact us if we can make this document more accessible: pdxscholar@pdx.edu. 
AN ABSTRACT OF THE THESIS OF Larry L. Sanders for the Master of

Science in Biology presented January 26, 1976.

Title: The Androgenic Glands of the Pacific Crayfish, Pacifastacus leniusculus trowbridgil Stimpson, 1859.

APPROVED BY MEMBERS OF THE THESIS COMITTEE:

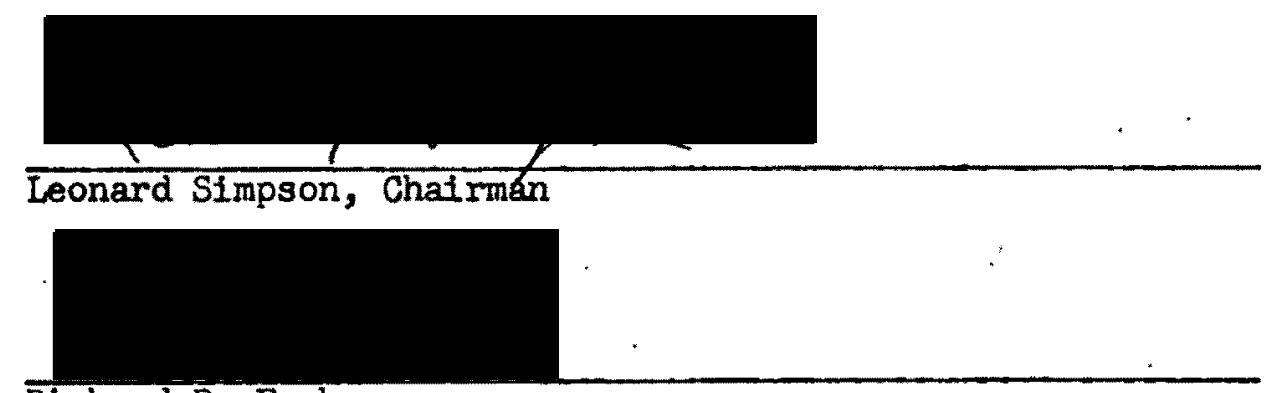

Richard B. Forbes

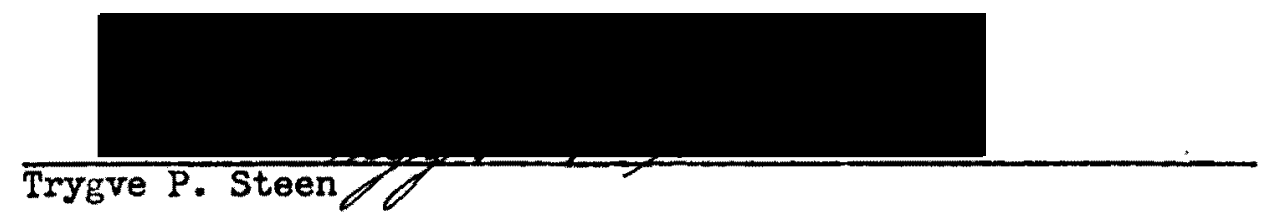

The androgenic glands of the Paciflc crayflsh, Pacifastacus

lentusculus trowbridgii Stimpson, 1859, were studied experimentally and by light and electron microscopy. The androgenic glands prolifarate in the spring of the year concurrently with an increase in mitotic activity in the testes. Degeneration of a major portion of the glands occurs in the fall, when spermatogenic activity in the testes is near completion. Cellular development appears to progress from small undifferentiated cells through stages of vacuolization and hypertrophy and terminates with degeneration or lysis. The fine structure of the 
vacuolated gland cells is indicative of increased metabolic activity and probable hormone secretion. However, experimental manipulation of the glands of $\underline{P}$. lentusculus gave no evidence of their presumed endocrine function. A discussion of the similarities of the androgentc glands with other known arthropod endocrine glands is also included. 
THE ANDROGENIC GLANDS OF THE PACIFIC CRAYFTSH, PACIFASTACUS LENIUSCULUS TROWBRTDGII

STIMPSON, 1859

by

LARRY L. SANDERS

A thesis submitted in partial fulfillment of the requirements for the degree of

MASTER OF SCIENCE

in

BIOLOCY

Portland State University

1976 
TO THE OFFICE OF GRADUATE STUDIES AND RESEARCH:

The members of the Commlttee approve the thesis of

Larry L. Sanders presented January 12, 1976.

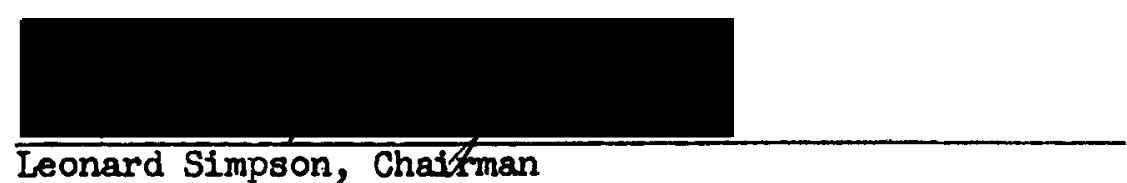

Leonard Simpson, Chastman

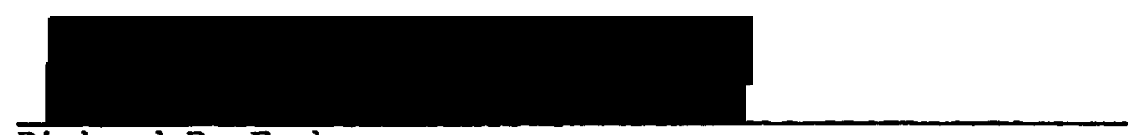

Richard B. Forbes

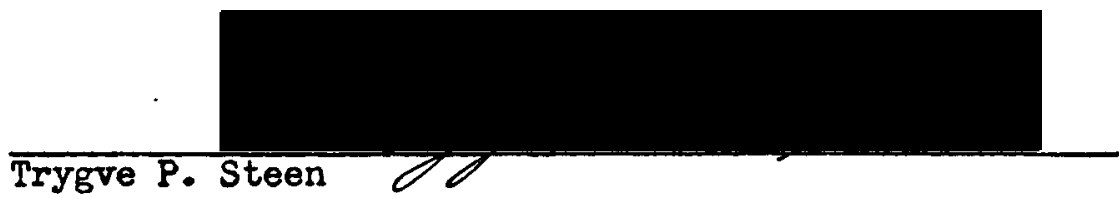

APPROVED

Earl Flsher, Jr., Head, Department of Blology

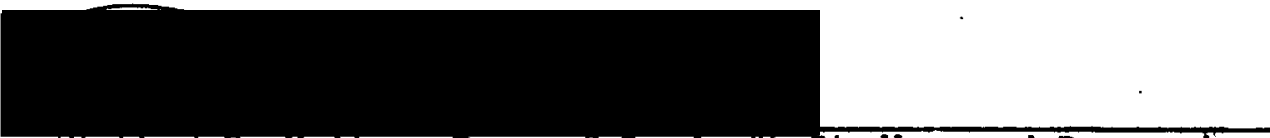

Richard B. Halley, Dean of Graduate Studies and Research

January 12, 1976 


\section{ACKNOWLEDGMENTS}

I am grateful to Dr. Richard Forbes and Dr. Trygve Steen for their assistance in the preparation of this thesis, and to Dr. Leonard Simpson for his unfailing support and instruction throughout the course of this research. I would also thank Nathalle Heger for her help with translation and for the crayflsh drawing, which is included in the Results section. Finally, I would acknowledge Sue Ann Sanders who gave me the opportunity to attempt this project. 
TABLE OF CONTENTS

PAGE

ACKNOWLFDGHENTS . . . . . . . . . . . . . . . . . i11

LIST OF TABLES ....................... . . . v

LIST OF FIGURES . . . . . . . . . . . . . . . . . vi vi

INTRODUCTION

REPRODUCTIVE CYCLE AND SEXUAL DIMORPHISM IN PACIFASTACUS $\cdot$ • 3

MATERIALS AND METHODS . . . . . . . . . . . . . . . 4

RESULTS ................................ 7

I MALE REPRODUCTIVE SYSTEM . . . . . . . . . . . 7

Light Microscopy

Electron Microscopy

II FEMALE REPRODUCTIVE SYSTEM . . . . . . . . . . 23

III Experimental Results ............... 25

Androgenic Gland Extirpation

Androgenic Gland Implantation

DISCUSSION . . . . . . . . . . . . . . . 30

BIBLTOGRAPHY . . . . . . . . . . . . . . . . 36 


\section{LIST OF TABLES}

TABLE

PAGE

I Correlation of Androgenic Gland Morphology and

Histology with Reproductive Morphology and

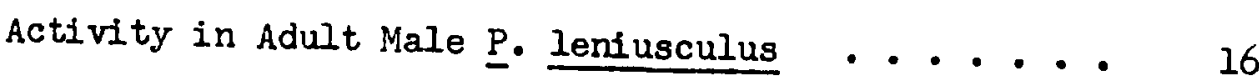

II The Sequence of Cellular Development in the Androgenic

Glands of Adult Male $\underline{P}$. leniusculus . . . . . . 22

III A Summary of the Results of Androgenic Gland Removal

and Implantation in P. lentusculus ....... 29 


\section{LIST OF FIGURES}

1. The Male Reproductive System of $\underline{P}$. Ieniusculus . . .

2. The Testes of $\underline{P}$. leniusculus Captured in Spring .....

3. The Testes of $\underline{P}$. Ieniusculus Captured in Early Summer...

4. Terminal Region of the Sperm Duct of $\underline{P}$. Ientusculus with an Associated Strand of Androgenic Gland Tissue .......................

5. Strands of Androgenic Gland Tissue from $\underline{P}$. leniusculus Captured during the Spring ..............

6. Androgenic Gland Mssue from P. Ientusculus Captured at the Time of the Annual Moult in Late Spring ....

7. Stage of Cellular Vacuollzation in the Androgentc Glands of $\mathrm{P}$. leniusculus ................

8. Vacuolatéd Androgenic Gland Cell fron P. Ieniusculus . - 20

9. Vitellogenic and Developing Ova in the Ovaries of 


\section{INTRODUCTION}

The androgenic glands of malacostracan crustaceans are epithelial endocrine glands which are the source of a hormone that is involved in the differentiation and maintenance of the primary and secondary sex characteristics of male animals (Charniaux-Cotton, 1960 and 1962; and Charniaux-Cotton and Kleinholz, 1964). First discovered in the amphipod, Orchestia gammarella (Charniaux-Cotton, 1954), the androgenic glands have since been identified in all major groups of malacostracan crustaceans (Charnfaux-Cotton et al., 1966; and Zerbib, 1967). The location, morphology, and histology of the androgentc glands in various malacostracan groups has been reviewed by Charniaux-Cotton et al., 1966, and a number of ultrastructural studies of the glands have been reported (King, $1964 \mathrm{a}$ and 1964b; Meusy, 1965; Malo, 1970; Malo and Juchault, 1970; Payen et al., 1971; and Payen, 1970 and 1972).

The purpose of this study was to describe the morphology, histology, and fine structure of the androgenic glands of the Pacific crayfish, Pacifastacus leniusculus trowbridgil Stimpson, 1859, and to undertake a series of extirpation-implantation experiments using androgenic gland tissue, in order to determine the function of these glands. There is substantial evidence of the endocrine function of the androgenic glands in amphipods and 1sopods (Charniaux-Cotton, 1954, 1960, and 1965; Katakura, 1967; and others), but evidence of gland function in the decapods is not as well documented. Studies of decapod androgenic gland function, using extirpation-implantation techniques, have 
been reported for both hermaphroditic (Charniaux-Cotton, 1959) and gonochorlstic species (Puckett, 1964; Payen, 1960 and 1969; and others). Previous studies of the androgentc glands of various crayfish species have dealt with; gland vascularization (Graf, 1962), gland function (Puckett, 1964), and gland morphology and histology (Carpenter and deRoos, 1970). King, 1964b, has described the fine structure of degenerating cells in the glands of Pacifastacus. 
REPRODICTIVE CYCLE AND SEXUAL DIMORPHISM IN PACIFASTACUS

Mason, 1963, has reported the life history of Pacifastacus leniusculus. Important reproductive events are as follows. Females become sexualiy mature in the third or fourth year after hatching. Maturity is indicated by an increase in abdominal width following the summer moult. Male crayflsh become sexually mature during the second or third year after hatching. Copulation takes place between September and late October, and is followed by spawning in October and early November. The eggs remain attached to the pleopods of the female during the winter, and hatching occurs in April and May.

Crayfish of the genus Pacifastacus exhibit external sexual dimorphism soon after hatching. Males differ from females in that the males posses five pairs of abdominal appendages, the pleopods, while females lack the flrst pair of pleopods. The $I^{\text {st }}$.pleopods of males, (Io gonopods), which eventually become modified for the transfer of sperm, are not present at hatching but appear when juvenile crayflsh reach $14 \mathrm{~mm}$ to $16 \mathrm{~mm}$ total length. The $2^{\text {nd }}$ pleopods, ( $2^{\circ}$ gonopods), are present at hatching and gradually differentiate to the adult form (Mason, 1963). The occurrence of a cycllc dimorphism of the gonopods, as observed in North American crayfish of the Family, Cambaridae, does not exist in Pacifastacus or other members of the Astacidae (Hobbs, 1974). 


\section{MATERIALS AND METHODS}

\section{Animal Collection and Maintenance}

Crayfish were collected from small streams in Washington and Multnomah Counties in Northwestern Oregon. Anfmals were taken during the period from March 1973 to November 1974. Winter collections were small due to the disappearance of animals from the stream beds durling the colder months of the year. Animals were maintained in the laboratory in a variety of temperature regulated containers. Oyster shell was used as a substrate, and larger rocks were added to provide cover for the animals. Tanks were aerated continuously and maintained at a varlety of water temperatures, $8^{\circ}$ to $20^{\circ}$ centigrade. All animals were fed beef IIver or frozen Ilsh every three days. Food remaining in the tanks was removed the mornting following the feeding perlod.

Histological Methods

Paraffin sections of the testes, sperm ducts, androgentc glands, and ovaries of normal, experimental, and control animals were prepared. Ovaries were flxed in Bouln's flutd, dehydrated in ethanol, sectioned at 10 microns, and stained with alum hematoxylin and cosin. Testes were flxed in neutral formalin or Bouln's fluid, dehydrated in ethanol, and sections were cut at 7 and $10 \mathrm{microns}$. Sections of the testes were stained with alum hematoxylin and eosin or iron hematoxylin and orange G. The sperm ducts and androgentc glands were flxed in neutral formalin, Zenker's solution, or Helly's solution, and dehydrated in 
ethanol. Sections were cut at varying thicknesses, 4 to $10 \mathrm{microns}$, and stained with alum hematoxylin and eosin, fron hematoxylin and orange $G$, or Mallory's triple stain.

The testes, sperm ducts, and androgenic glands were also embedded in Epon. Tissue removed from anesthesized or recently kdlled animals was placed directly in $2.5 \%$ glutaraldehyde buffered with phosphate at a $\mathrm{pH}$ of 7.4. After rinsing in buffer, the tissue was postfixed in 18 $\mathrm{OsO}_{4}$ in an ice bath. THssues were dehydrated in an ethanol series and embedded in Epon (Luft, 1961). Sections were cut on a Porter-Blum Ultramtcrotome using glass kntres. One micron sections were statned with Richardson's stain (Richardson et al., 1960) and with 18 basic fuchsin. Thin sections were picked up on uncoated 300 mesh copper grids, stained with uranyl acetate and lead citrate, and viewed with a Zeiss EM 9S-2 electron microscope.

Experimental Methods

Removal of the androgenic glands was accomplished as follows: Animals were anesthesized with $\mathrm{CO}_{2}$ and secured to cork pinning boards ventral side up. The coxapodites of the fourth walkdng legs were then disarticulated from their connections with the ventral and branchial regions of the thorax and pulled away from the animal. This procedure exposed the sperm ducts which were cut with iridectomy scissors. The coxapodites were placed in crayfish saline (van Harreveld, 1936), and the terminal region of the sperm duct and its attached androgenic gland were then removed from the coxapodite. The wounds produced by the removal of the coxapodites were cauterized and covered with warm paraffin. The operated animals were allowed to recover from the operative pro- 
cedure in individual recovery tanks, and wore returned to the appropriate experimental tank after a sufficient recovery period. Control animals were subject to the same operative procedures as the exparimental animals except that the coxapodites of the third walking legs were removed.

Androgenic gland tissue was implanted in females that raried in size from 15 to $30 \mathrm{~mm}$ carapace length. The gland tissue was implented in the ventral abdominal sinuses through small incialons in the ventral exoskeleton. The incisions wero sealed with warm paraffin. Females were not anesthesized, but were allowed a perfod of post-operative recovery in individual recovery tanks before being returned to oxperimental tanks. Female controls were given implants of muscle tissue from the third walking legs of male crayfish.

Androgenic glands were also implanted into the thoracic cavity of some females using the following method: Androgenic gland tissue recently removed from the coxapodites of male crayflish was drawn into $1 / 2$ cc glass syringes along wh $0.2 \mathrm{ml}$ of crayflsh saline. An 18 gauge hypodermic needle was attached to the syringe and the contents of the syringe were injected into the dorsal thoracic cavity, through the connective tissue which separates the thorax from the abdomen. This method minimized the loss of hemolymph and appeared to cause less shock to the animal than the previous method. Injected animals were then allowed a period of recovery, and were returned to experimental tanks. Operated animals were observed regularly and at various intervals were sacrificed and examined histologically. 


\section{RESULTS}

The morphology and histology of the reproductive systems of both male and female $\underline{P}$. leniusculus vary according to the size and state of maturity of the individual animal. Seasonal differences in the form and structure of the reproductive organs correspond with the production of gametes and to a lesser extent with the moult cycle stage of the animal.

\section{MALE REPRODUCTIVE SYSTEM}

\section{Light Milcroscopy}

Testes. The testes of $\underline{P}$. leniusculus are compound acinar organs which are located in the dorsal thoracic cavity below the pericardial cavlty and dorsal to the posterior lobes of the digestive glands. The testes are trilobed structures with two anterior lobes extending to the region of the cardiac stomach and one posterior lobe which extends into the flrst or second abdominal segment ( $\mathrm{Mg} .1$ ). Individual testicular acini, which are surrounded by a thin connective tissue sheath, consist of a variable number of germ cells and a pertpheral layer of 1rregularly shaped accessory cells. Groups of acini are connected by ducts or collecting tubules which are composed of a cellular lining surrounded by connective tissue. Larger collecting tubules, which foin to form the sperm ducts, are also surrounded by layers of circular muscle tissue.

The annual production of spermatozoa can be separated into four 


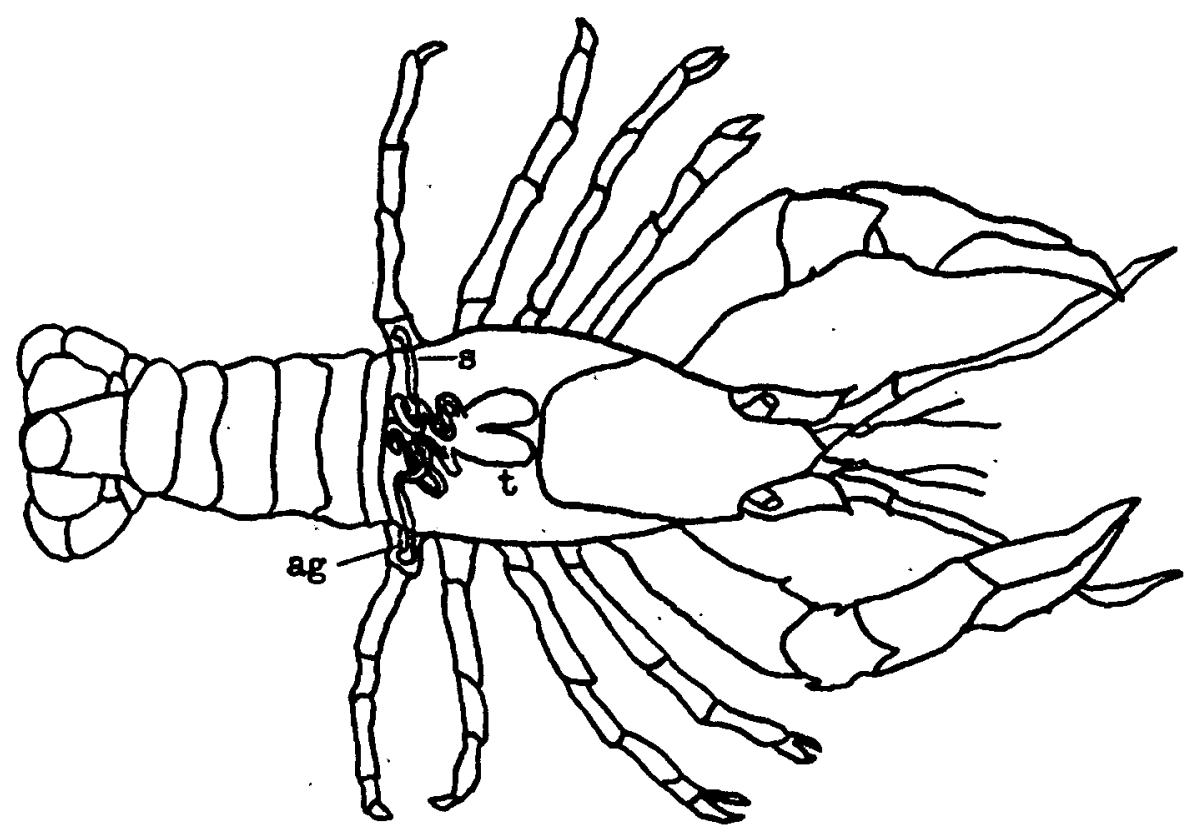

Figure 1. The male reproductive system of $P$. lentusculus. Diagrer indicates the location of the testes $(\bar{t})$, sperm ducts $(\mathrm{s})$, and the androgenic glands (ag).

reasonably distinct stages which correspond roughly to the seasons of the year. In the late fall and winter months, following copulation, the testes contain a minimum number of germ cells and in most animals appear to be in a disorganized, nonfunctional state. Spermatozoa, and the mucous-like secretion of the epithelfal lining of the collecting tubules, are occasionally found in the testes of mature crayflish captured after the copulatory period. However, copulation or the discharge of spermatozoa was not observed in any of the natural stream populations in the months following the normal copulatory period. During the later phases of the post-copulatory period, mitotically dividing germ cells are observed with increasing frequency, and a gradual reorganization of the testes tissue occurs. In the spring, March to May, testicular activity increases. Numerous mitotically dividing germ 
cells are observed, and the size of the testes increases measurably in most animals (FIG - 2). Melotic cell division is flrst observed in the

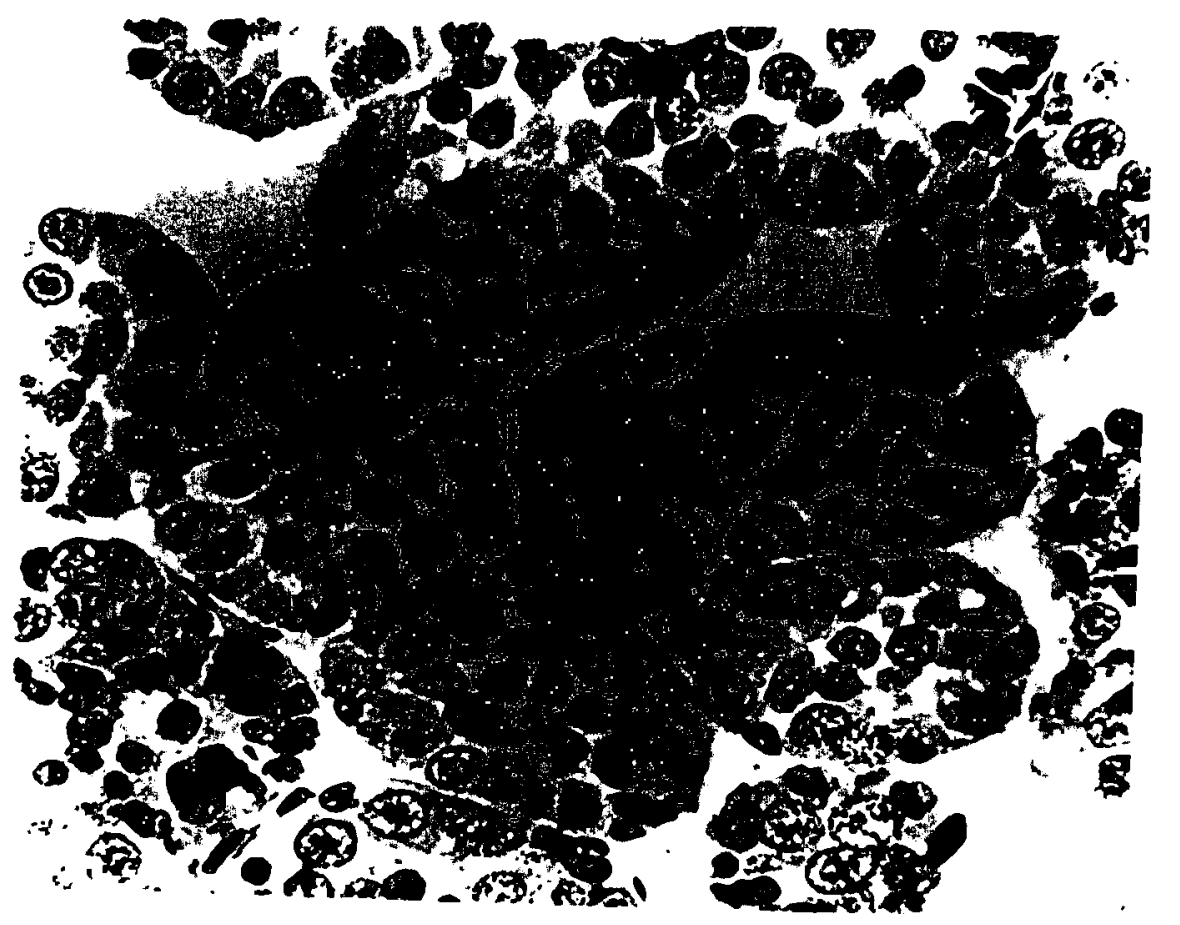

Figure 2. The testes of P. leniusculus captured in the spring. Mear. Spermatolically difing germ cells are numerous at this time of the (a). $260 \mathrm{X}$.

early summer months, during the premoult phase of the yearly moult cycle of mature males. Spermatogenesis proceeds rapidly following ecdysis (Fig. 3). Spermiogenesis occurs in the actini and collecting tubules during late summer. Spermatozoa are present in the collecting tubules and sperm ducts in early fall, and at this time the testes and sperm ducts are the most obvlous structures in the dorsal thoracic cavity.

Sperm Ducts. The sperm ducts arise near the junction of the 


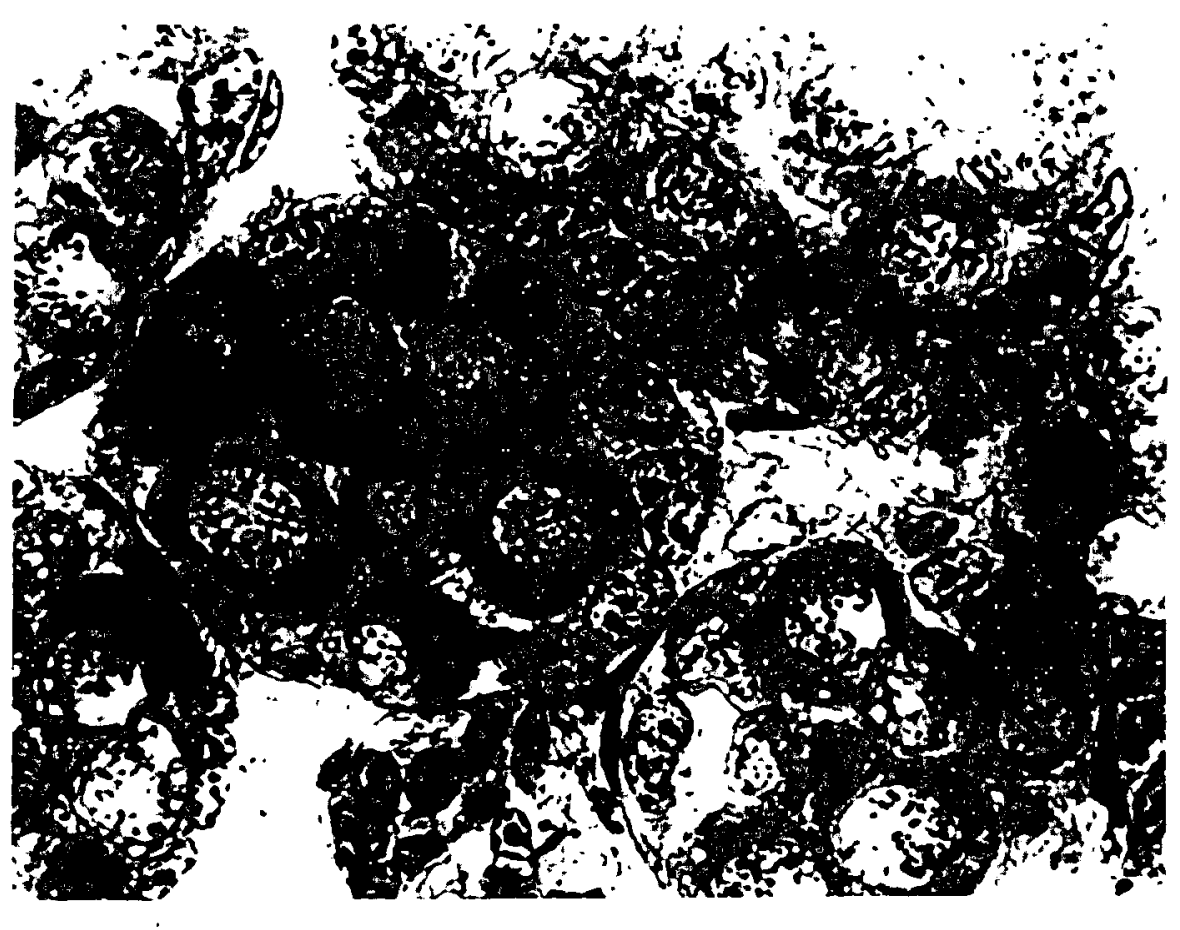

Flgure 3. The testes of $P$. lentusculus captured in early summer. Spermatogenesis proceeds rapidly in the testes at this time of the year. Spermatogonia (sg), spermatocyctes (sc), accessory cells (a). $400 \mathrm{X}$.

posterior and anterior lobes of the testes (Fig. 1). Histologically, two regions of the sperm ducts can be identifled. In the dorsal thoracic cavity, the sperm ducts are highly colled structures situated dorsal to the lobes of the testes. In this region, the ducts consist of an eptthelial lining of densely staining secretory cells surrounded by layers of circular and longltudinal muscle fibers. The pseudostratified epithelial cells have large oblong nuclei with granular or ribbon like chromatin and diffusely staining cytoplasm. In the posterior region of the thoracic cavity, the sperm ducts become uncoiled and extend ventrolaterally into the coxapodites of the $4^{\text {th }}$ walking legs. Upon entering the coxapodite, the sperm duct bends medially and opens toward 
the ventral midline of the animal. The terminal region of the sperm duct is similar to the more proximal reglons except that the muscular sheath is greatly enlarged in the terminal region. The onlarged muscular sheath of the terminal regions of the duct consists of circular and longitudinal muscle layers (Fig. 4).

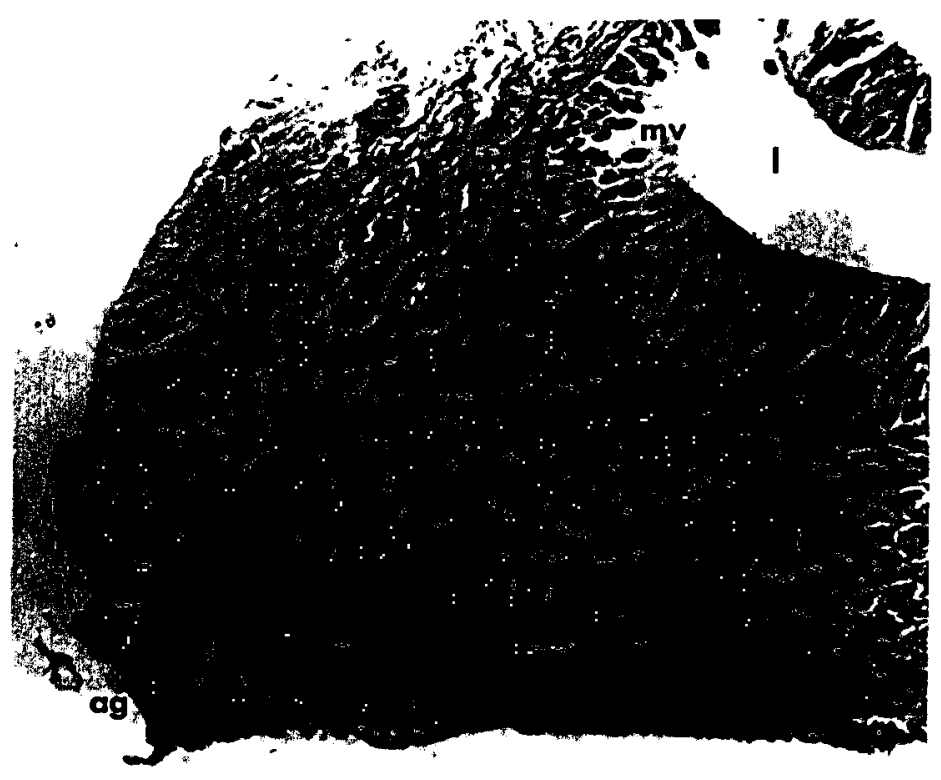

Flgure 4. Terminal region of the sperm duct of $P$. lentusculus with an associated strand of androgentc gland tissue. Lumen of the duct (l), secretory epi thellal cell layer (e), circular muscle (c), longltudinal muscle (m), microvillar arface of epithelial cells (mv), androgenfc gland tlasue (ag). $160 \mathrm{X}$.

Maximum presecretory development of the epithelial cells appears to occur at the time of the yearly moult. At this time, nuclel stain Intensely with hematoxylin and contain large spherical messes of chromatin. Microvilis stain with relatively strong intensity in iron hematoxylin and extend a maximum distance into the empty lumen of the duct. Cell division is observed infrequently in the epithelial cells, except in animals captured during the late spring and sumer. In these ant- 
mals, dividing cells are distinguishable in both regions of the duct. The epithelial cell lining of the entire duct is at the height of secretory activity in late summer and fall. In late fall, at the time of copulation, spermatozoa and the mucous-like secretion of the epithelial cells fill the lumen of the duct.

Androgentc Glands. The androgenic glands of $\underline{P}$. Ientusculus are located in the loose connective tissue which surrounds the terminal muscular regions of the sperm ducts. The morphology and histology of the androgenic glands vary according to the t1me of the year in which the animal is captured and to the size of the animal. The glands of mature crayfish undergo a yearly cycle of development which includes phases of proliferation and degeneration (Table I).

Androjenic gland tissue is difficult to locate in animals captured during the winter months. In these animals, the glands appear as small strands of tissue situated at the perfphery of the sperm duct musculature (Fig. 4). Gland cells are small, 4 to 7 microns, with irregularly shaped nuclei. Small dense masses of chromatin are located throughout the nuclei of these cells. Mitotic figures are not observed, and cell boundaries are indistinct at this time of year.

Eeginning in early spring, the androgenic glands are found in a majority of captured animals. Proliferation of the glands occurs at this time, and gland tissue is often observed as parallel and anastomosing strands of cells in the loose connective tissue of the coxapodites. Strands of gland tissue in sheet-like masses are also found near the muscular sheath of the sperm ducts. Individual strands of cells are surrounded by a thin layer of connective tissue, which is 
also interspersed among, the gland t1ssues in layer-like arrangements. The diameter of gland cells from animals captured in the spring is generally 2 to 5 microns larger than that of cells from winter animals, and the increase in gland size during thts period is probably due to cell growth (Fig. 5). As spring progresses, dividing cells are observed in the larger strands of gland tissue. Cell division often occurs simultaneously in all the cells of a single strand of tissue, but mi tosis is occasionally observed in single gland cells located in the connective tissue of the gland mass.

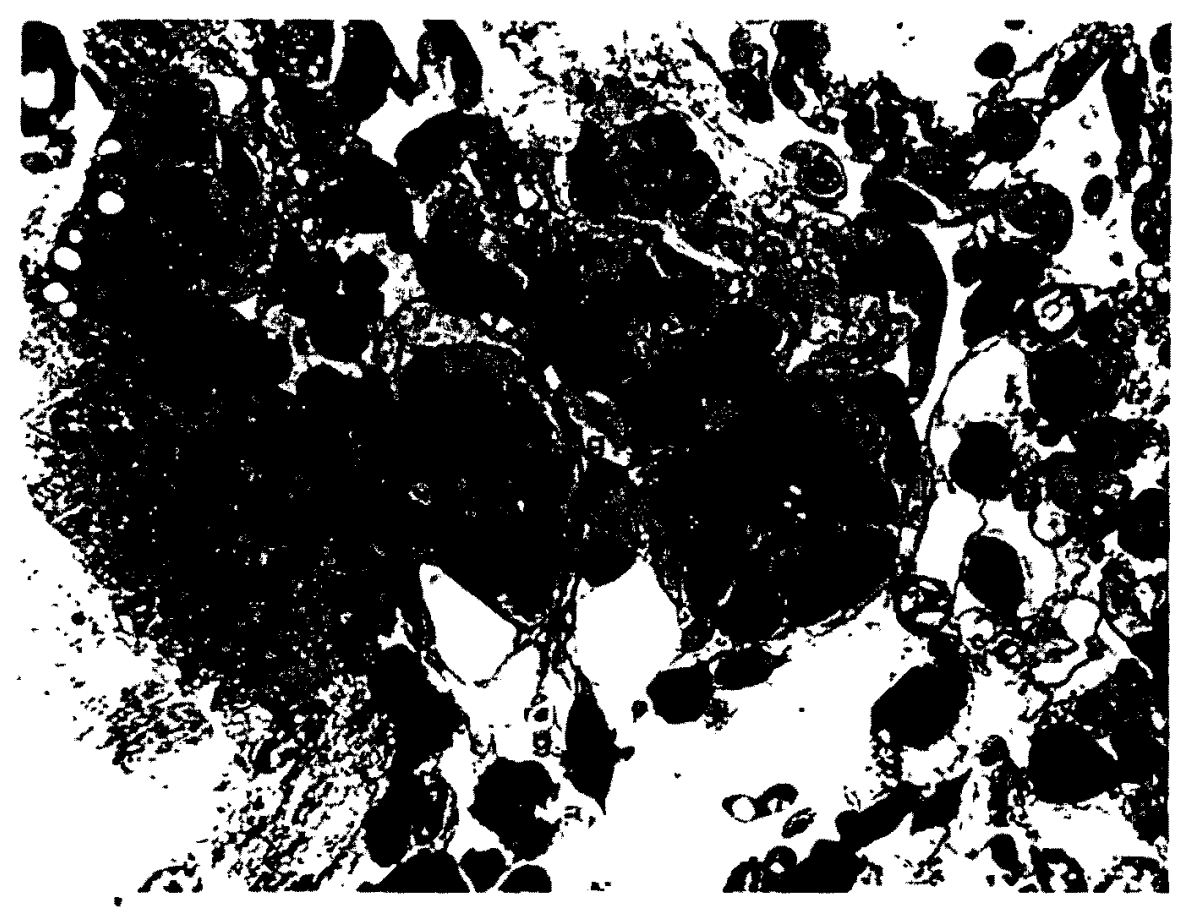

Figure 5. Strands of androgenic gland tissue from P. leniusculus captured during the spring. The increase in gland $s i z e$ at this time is due mainly to cell growth. Androgenic gland tissue (ag), connective tissue (c), granular hemolymph cells (g), hypodermis of coxapodite $(h) .400 x$.

In late spring, at the time of the yearly moult of mature males, 
cellular diversity is at a maximum within the prollferating gland tissue. In addition to strands containing the developing cells previously described, three other cell types are commonly observed in this proliferating tissue. Larger cells, 12 to 16 microns in diameter, with highly vacuolated cytoplasm, are found in strands of 60 to 80 microns In diameter (Fig. 6). Cells of this type are characterized by irregularly shaped nuclei with peripheral chromatin. Vacuolization of the cytoplasm is extensive, and strands of cells are encountered in which the central region of the strand is fliled with large vacuoles. The cell boundaries of this cell type are indistinct in parafin and Epon

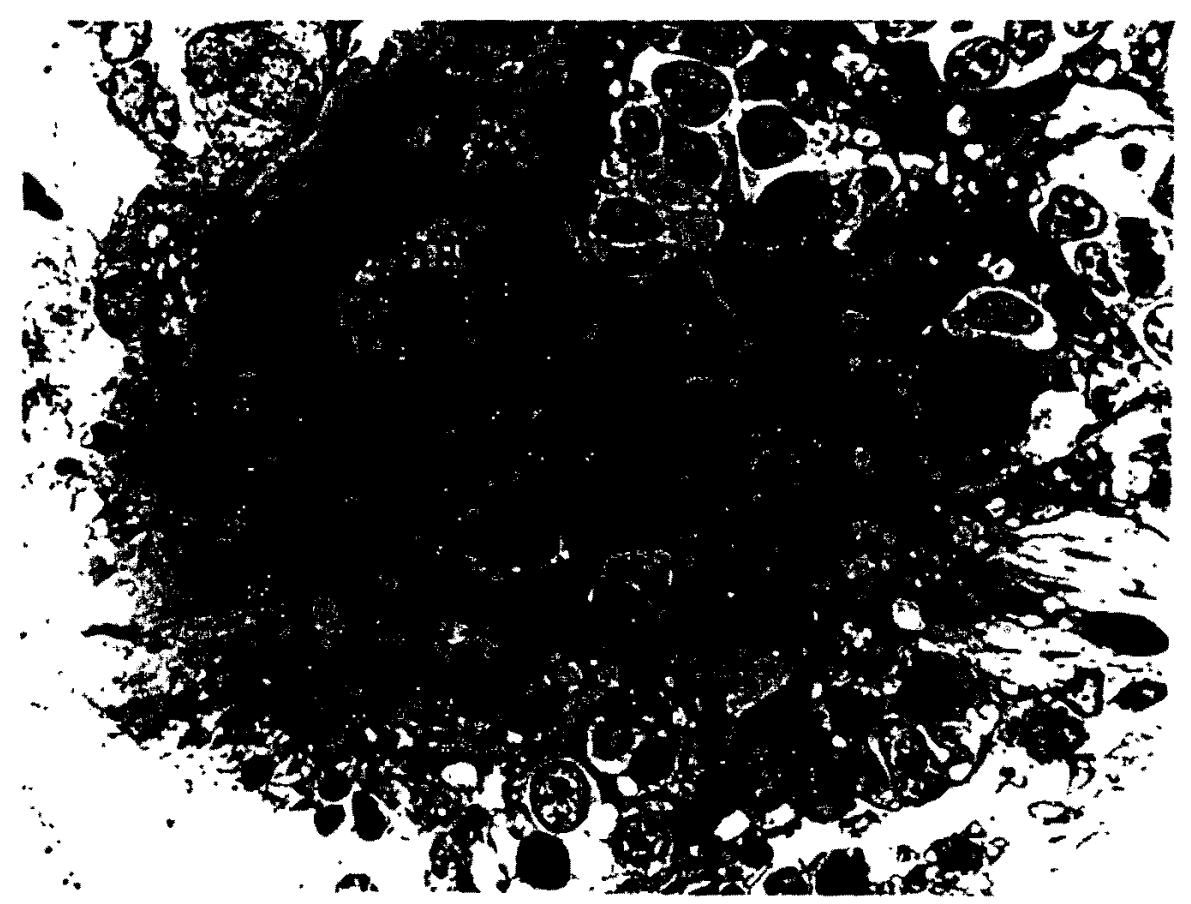

Figure 6. Androgenic gland tissue from $P$. leniusculus captured at the time of the annual moult in late spring. Cells in various stages of development are present in this proliferating t1ssue. Dividing cells (d), vacuolated cells $(\nabla)$, degenerating cells $(p)$. $400 x$. 
sections. The fourth recognizable cell type is found in strands of maximum diameter, 70 to 90 microns. Cells in this stage of development are of maximum size, 14 to $18 \mathrm{mlcrons}$ in diameter, and have spherical nuclei. Cell boundaries are usually distinct in paraffin and Epon sections, and granules and inclusions are observed in the cytoplasm. The extensive cytoplasmic vacuolization described in the previous developmental stage does not occur in this cell type. Instead, cellular hypertrophy appears to be occurring. The fifth cell type, observed during the late spring and encountered with increasing frequency throughout the following months, is the terminal stage of cellular development. Cells of this type have intensely staining pycnotic nuclei, and highly disrupted vesicular cytoplasm (FIg. 6). Inclusions and granules are often found in the cytoplasm, and the connective tissue sheath of strands of these cells is fragmented and discontinuous.

In the summer months the androgentc glands reach their madmum size and volume. For the most part, the glands consist of strands of hypertrophied and degenerating cells. Following ecdjeis, strands of cells in earlier stages of development are observed infrequently, if at all. In the fall, gland size diminishes rapidly. Nuclear pycnosis is commonly observed in the gland mass of mature males, and in most anjmals the glands appear to be degenerate and nonfunctional.

Electron Microscopy

Androgenic Glands. As with paraffin sections, observation of androgenic gland fine structure reveals a yearly cycle of cellular proliferation and degeneration. Cellular development, however, is not synchronous throughout the entire gland mass. During most of the 


\section{TABLE I}

CORRELATION OF ANDROGENIC GLAND MORPHOLOGY AND HISTOLOGY WITH REPRODUCTIVE MORPHOLOGY AND ACTIVITY

IN ADULT MALE P. LENIUSCULUS

\begin{tabular}{|c|c|c|c|c|c|}
\hline & Spring & Summer & Fall & & Winter \\
\hline$\cdots$ & - Ecdysis & Postmoult & moult & Copulation & $\cdots$ \\
\hline Testes & \multirow{2}{*}{$\begin{array}{l}\text { Increase in size from } \\
\text { winter. Mitotic ac- } \\
\text { tivity increases. } \\
\text { Usually empty of } \\
\text { sperm. Small number } \\
\text { of dividing cells in } \\
\text { epithelial lining. }\end{array}$} & \multirow[t]{2}{*}{$\begin{array}{l}\text { Spermatogenesis pro- } \\
\text { ceeds rapidly. Sperm } \\
\text { in acini. }\end{array}$} & \multicolumn{2}{|c|}{$\begin{array}{l}\text { Cessation of melotic } \\
\text { activity. Sperm in } \\
\text { actini and tubules. }\end{array}$} & $\begin{array}{l}\text { Reorgantzation of tis- } \\
\text { sues. Gradual increase } \\
\text { in germ cell numbers. }\end{array}$ \\
\hline Sperm Ducts & & & $\begin{array}{l}\text { Sperm and } \\
\text { cell secr } \\
\text { duct lumer } \\
\text { not obser } \\
\text { ular lini }\end{array}$ & $\begin{array}{l}\text { epi thelial } \\
\text { tion in } \\
\text {. Mitosis } \\
\text { red in cell- } \\
\text { a. }\end{array}$ & $\begin{array}{l}\text { Jaually contain some } \\
\text { sperm. Epithelial cell } \\
\text { division not observed. }\end{array}$ \\
\hline
\end{tabular}

\begin{tabular}{|c|c|c|}
\hline $\begin{array}{r}\text { Androgenic } \\
\text { Glands: }\end{array}$ & .... Proliferation .... & .. Deger \\
\hline Morphology & $\begin{array}{l}\text { Parallel and anasto- } \\
\text { mosing strands of } \\
\text { cells. Larger diam. } \\
\text { strands usually some } \\
\text { distance from ducts. }\end{array}$ & $\begin{array}{l}\text { Similar to spring, } \\
\text { also in sheet-like } \\
\text { masses. Maximum } \\
\text { gland size. }\end{array}$ \\
\hline Histology & $\begin{array}{l}\text { Structurally diverse } \\
\text { cellular strands. Cell } \\
\text { division occurring. } \\
\text { Vacuolated and degen- } \\
\text { erating cells present. }\end{array}$ & $\begin{array}{l}\text { Vacuolated and hy- } \\
\text { pertrophied cells } \\
\text { predomnant. Degen- } \\
\text { erating cells with } \\
\text { pycnotic nuclei. }\end{array}$ \\
\hline
\end{tabular}

Decreasing number of large diam. strands. Strand degeneration prevelant.

Strands consist of hypertrophied and degenerating cells.
Small number of cellular strands in muscle and connective tissue of sperm ducts.

Undifferentiated cells in small diameter strands. 
year, strands of cells differing structurally are observed in the glands. Structural variation in noighboring strands of cells is most often observed in the glands of late premoult animals.

The cellular developmental cycle, in the glands of $\underline{P}$. leniusculus, appears to be initiated in early spring (Table II). The majority of cells, at this time of year, have irregularly shaped nuclei and uniformly dense cytoplasm. Cytoplasme organelles, such as mdtochondria and Golgt bodies, are fow in number and scattered throughout the cytoplasm. A relatively small amount of endoplasmbc reticulum, both granular and agranular, is also observed in these cells.

As cellular development proceeds, Individual cells increase in size. Cell growth is accompanted by an increase in the number and complexity of cytoplasmic organelles. Large numbers of tubular or spherical mitochondria with transverse cristae are found in these cells, and a large amount of sac-like or vestcular agranular endoplasmic reticulum is frequently observed. Cell division is observed most often in cells of this type. A common feature of developing gland cells is an extensive infolding of the cell membrane, especially in cells at the periphery of the strands of gland tissue. These so called "interdigitating membranes" are a feature of all cellular stages except the terminal degenerative stage. In some cells, the infolding membranes separate the peripheral cytoplasm from the more central reglons of the cell. Vacuollzation of the cytoplasm of gland cells is a normal stage in the cellular developmental cycle. Vacuolated cells are observed regularly in the glands of crayfish in late premoult phases. Cells in this stage of development, contain numerous tubular and spherical mito- 
chondria with transverse cristae (Fig. 7). In addition, extensive fields of agranular endoplasmic reticulum are observed, often surrounding vacuoles of various size. The nuclei of these cells are often pear-shaped with densely staining peripheral chromatin and a single, more centrally located nucleolus. In non-localized regions, the periphery of the nucleus is scalloped in appearance, with numerous closely spaced indentations. Cell membranes, with numerous infoldings, are usually distinct, and electron dense regions between neighboring membranes are commonly encountered. As mentioned above, vacuoles are often associated with flelds of agranular endoplasmic reticulum. In some regions of these cells, however, vacuoles appear to be closely associated with swollen distorted mitochondria. The vacuoles are of varying size and shape in these cells. Smaller, spherical vacuoles are usually membrane bound and located in intracellular regions. Larger, 1rregularly shaped vacuoles lack membranes, and often extend into the cytoplasm of adjoining cells.

In cells undergoing extensive vacuolization, a number of unique structures are observed $\left(\mathrm{FH}_{\mathrm{g}}\right.$. 8). Larger vacuoles, up to $5 \mathrm{microns}$ in diameter, are often surrounded by layer-like arrangements of electron dense, agranular membranes. The cytoplasm immediately surrounding these electron dense membranes is often filled with small tubular and spherical vesiclès. Electron dense, membrane bound granules, characteristic of Golgl systems, are not encountered in these cells. Mitochondria are characteristicly swollen and distorted, and in various phases of vacuolization. Spherical clusters of membranes, in concentric layer-like arrangements, are also found in these cells. These 
multi-lamellar bodies are similar in size to the spherical mitochondria but lack an electron dense matrix.

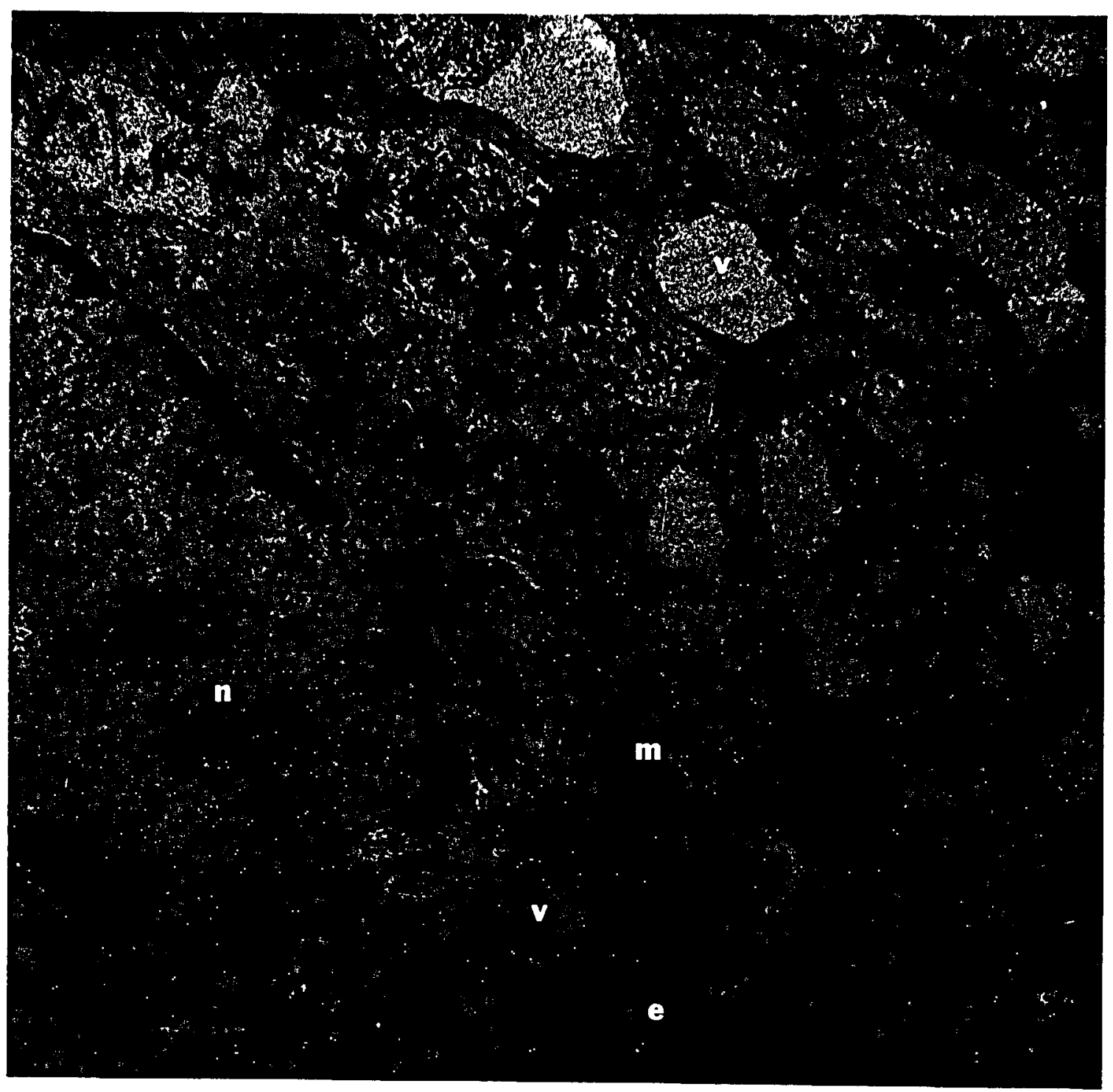

Flgure 7. 'Stage of cellular vacuollzation in the androgenic glands of $P$. leniusculus. This stage of cellular development coincides with the annual moult of mature males. Mitochondria $(m)$, endoplasmic reticulum $(e)$, vacuoles $(v)$, nucleus $(n)$. $5000 \mathrm{X}$. 


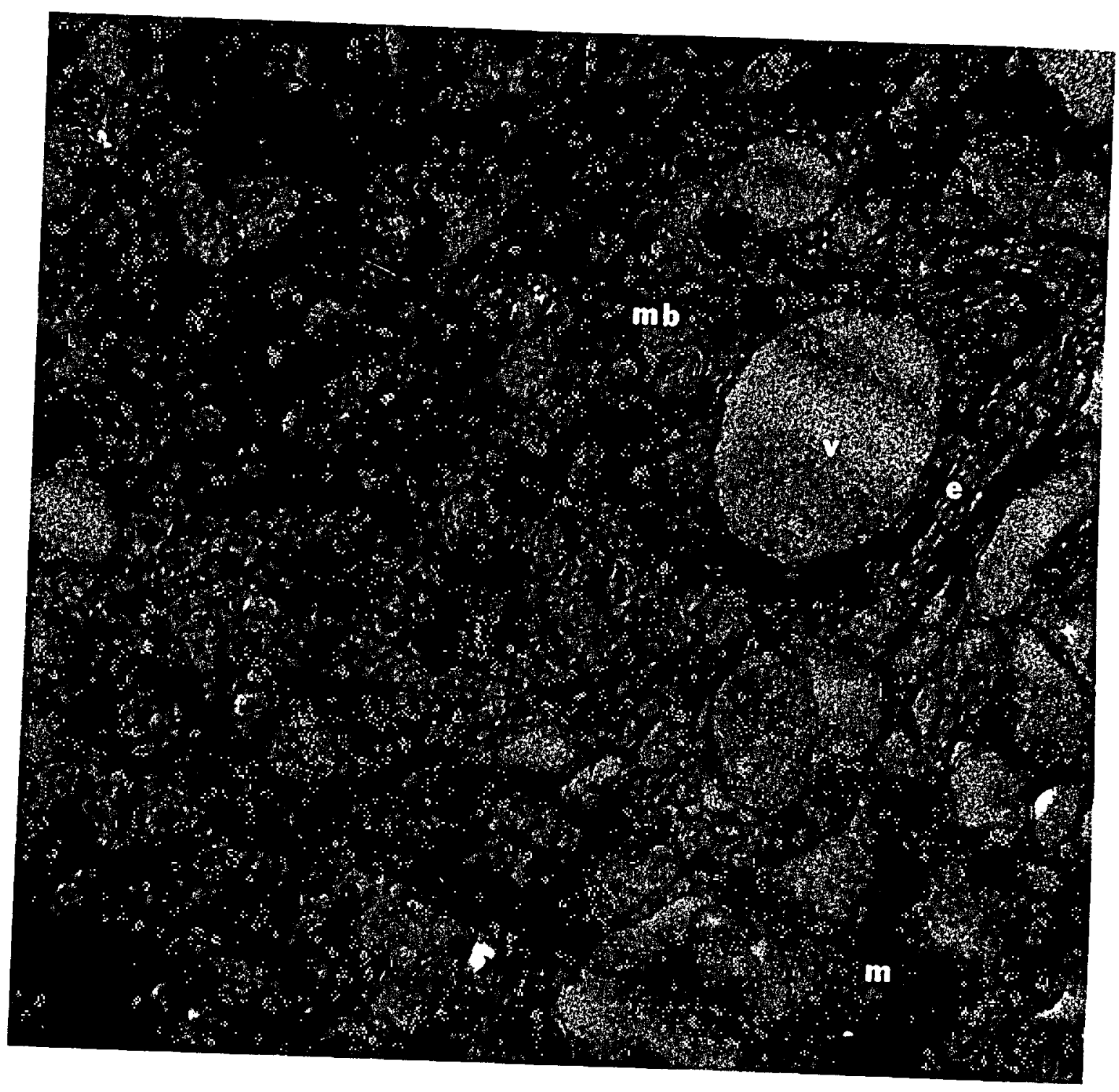

Figure 8. Vacuolated androgenic gland cell from P. leniusculus showing the structural relationship of the lamellar membrane sistems (e), mitochondria (m), multi-lamellar bodies (mb), and
vacuoles (v). $8500 \mathrm{x}$.

Following the stage of vacuolar activity, androgenic gland cells reach their maximum size. These cells, characteristicly, have spherical nuclei and diffuse, vesicular cytoplasm. Mitochondria and endoplasmic reticulum are difficult to identify, although, in some cells, 
agranular membrane systems, in lamellar arrangements, do exist. Golgi bodies and vesicles, though never abundant in androgenic gland cells, are observed most frequently in cells of this type. Membrane bound Granules are also found in these cells, but never in great numbers. Following the stage of maximum cell size or hypertrophy, the termịnal degenerative stage of cellular development occurs. Cells in this stage of development have spherical, uniformly dense nuclei and numerous cytoplasmic vesicles and granules. The nuclear membranes or de irenerating, pycnotic nuclei are often swollen and distorted, and in later phases of degeneration, fragmentation of the nuclei occurs. Mitochondria and fields of endoplasmic reticulum are rarely distinguishable, although Golgi systems are observed in some cells. The connective tissue sheath, surrounding strands of these cells, is often fragmented, and frequently, vesicles and granules are observed in regions peripheral to the strands. 
TABLE II

THE SEQUENCE OF CELLULAR DEVELOPNENT IN

THE ANDROGENIC GLANDS OF ADULT MALE

P. LENIUSCULUS.

\begin{tabular}{|c|c|c|c|c|}
\hline Stage & $\begin{array}{c}\text { Cell } \\
\text { Diameter }\end{array}$ & Cell Ultrastructure & $\begin{array}{c}\text { TIme of Year } \\
\text { Observed }\end{array}$ & Remarks \\
\hline I & $4-7 \mu$ & $\begin{array}{l}\text { Uniformly dense cytoplasm, with few mito- } \\
\text { chondria and a small amount of endoplasmic } \\
\text { reticulum. Nuclei are irregular in shape with } \\
\text { densely staining masses of chromatin. }\end{array}$ & $\begin{array}{l}\text { Winter } \\
\text { and } \\
\text { Spring }\end{array}$ & $\begin{array}{l}\text { Undifferentiated } \\
\text { cells. }\end{array}$ \\
\hline II & $8-12 \mu$ & $\begin{array}{l}\text { Increase in the number of cytoplasmic or- } \\
\text { ganelles. Golgl bodies and vesicles not fre- } \\
\text { quently encountered. Nuclei are irregular in } \\
\text { shape with a centrally. located nucleolus. } \\
\text { Cell division is common in cells of this size. }\end{array}$ & $\begin{array}{l}\text { Early Spring } \\
\text { to } \\
\text { Early Summer }\end{array}$ & $\begin{array}{l}\text { Stage of cell } \\
\text { growth and } \\
\text { division. }\end{array}$ \\
\hline III & $12-16 \mu$ & $\begin{array}{l}\text { Mitochondria and agranular endoplasmic re- } \\
\text { ticulum associated with vacuoles, both } \\
\text { membrane bound and lacklng membranes. Nuclei } \\
\text { with numerous indentations and peripheral } \\
\text { masses of chromatin. Nucleoli regularly } \\
\text { observed. }\end{array}$ & $\begin{array}{l}\text { Spring } \\
\text { and } \\
\text { Summer }\end{array}$ & $\begin{array}{l}\text { Stage of cyto- } \\
\text { plasmic vacuol- } \\
\text { ization. }\end{array}$ \\
\hline IV & $14-18 \mu$ & $\begin{array}{l}\text { Mitochondria, when observed, are swollen or } \\
\text { vacuolated. Golgi systems more frequent than } \\
\text { in earlier stages. Nuclei are spherical with } \\
\text { electron dense chromatin throughout. Cytoplasm } \\
\text { is vesicular and contains some granules. }\end{array}$ & $\begin{array}{l}\text { Spring } \\
\text { to } \\
\text { Late Summer }\end{array}$ & $\begin{array}{l}\text { Continuation of } \\
\text { vacuolar proces- } \\
\text { ses. Cellular } \\
\text { hypertrophy. }\end{array}$ \\
\hline$V$ & $\cdots$ & $\begin{array}{l}\text { Cytoplasm is vesicular, with granules commonly } \\
\text { observed. Nuclei are unf formly dense and in } \\
\text { some instances fragmented. Cell membranes are } \\
\text { often discontinuous and cell contents are } \\
\text { observed in surrounding regions. }\end{array}$ & $\begin{array}{l}\text { Spring } \\
\text { to } \\
\text { Fall }\end{array}$ & $\begin{array}{l}\text { Cell degenera- } \\
\text { tion and lysis. }\end{array}$ \\
\hline
\end{tabular}




\section{FEMALE REPRODUCTIVE SYSTEM}

The ovaries of female $\underline{P}$. leniusculus are similar to the testes in shape and location. Paired oviducts arise near the juncture of the two anterior lobes of the ovaries and extend ventrolaterally into the coxapodites of the $2^{\text {nd }}$ walkding legs. The oviducts open on the medial surface of the coxapodites, toward the ventral midline of the animal.

The ovaries of all animals examined contained ova in various stages of development and yolk storage. The ovaries of females nearing sexual maturity, 25 to $30 \mathrm{~mm}$ carapace length, contain numerous yolk filled ova, with a maximum diameter of 1 to $2 \mathrm{~mm}$. Smaller females have correspondingly fewer ova of this type. Vitellogenic ova are surrounded by a single layer of follicle cells (Fig. 9). In cross section, individual follicular cells are oblong in shape and contain spherical, densely staining nuclei. The nuclei of vitellogenic ova stain with varying intensity and granular inclusions are often observed in the spherical nuclear mass. The yolk of these ova is often pigmented, and yolk near the periphery of the ova is globular in appearance.

Germ cell development, preceeding the stage of yolk storage, occurs in the central region of each of the ovarian lobes. As would be expected, the ovaries of smaller, immature crayfish contain greater numbers of meiotically dividing germ cells than do those of females nearing sexual maturity. 


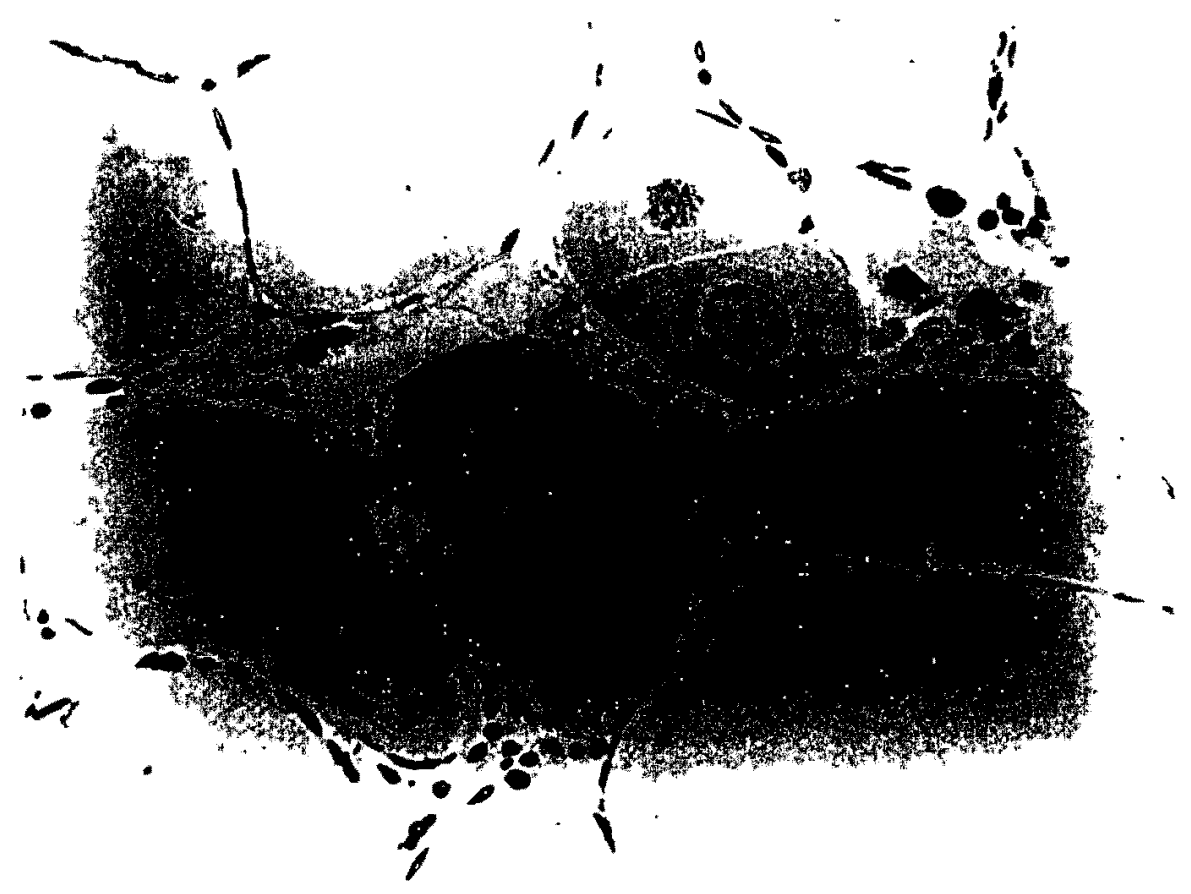

Figure 9. Viteilogenic and developing ova in the ovaries of P. Ieniusculus. Yclk filled ova are numerous in the ovaries of females nearing sexual maturity, while the earlier developmental stages of crayfish ova are more commonly encountered in smaller, immature animals. Vitellogenic ova ( $v)$, developing ova (d), follicular linting (f). $160 \mathrm{x}$. 


\section{EXPERIMENTAL RESULTS}

\section{Androgenic Gland Extirpation}

Androgenic glands were removed from male crayfish ranging in size from 18 to $40 \mathrm{~mm}$ carapace length. Crayfish of this size range include those in their second through fourth years. Glands were removed from two groups of crayfish during the spring and late summer, and animals were maintained for periods varying in length from 4 to 60 days. Mortality rates for operated males were relatively high, 20.6 , with death usually occurring in the first post-operative day. Surviving animals recovered rapidly, and wound tissue was observed on the base of the excised coxapodites within 5 days. Moulting in operated and control animals occurred at approximately the same time. However, the moult cycle stage of controls from natural stream populations was found to vary from that of laboratory animals during both spring and late summer. In rost cases, tine laboratory animals were found to be in an advanced stage of the moult cycle.

As described previously, the testes of normal, spring animals contain numerous mitotically dividing germ cells, and by late spring meiotically dividing cells are observed. The sperm ducts of these animals $h$.ve a well developed epithelfal cell lining, and the androEenic glands are prolfferating (Table III). The testes of experimental animals are similar to those of the controls. Germ cell activity is high, and meiosis is observed in animals sacrificed later in the spring. Sperm duct histology is much like that of the controls except that in 
some operated animals the tissue adjacent to the surgical site undergo degeneration. Tissue in degenerating regions contains numerous granular henolymph cells and layers of dense, brittle material. Degeneration of the ducts of experimental males is observed to proceed from the severed end of the duct toward the more proximal regions. Degeneration of sperm duct tissue occurred in only a small percentage of operated animals, and it probably was caused by infection or mechanical damage from the operative procedure. Differences in the behavior of operated and control animals were not observed.

The testes of animals captured in late summer contain germ cells in the later stages of spermatogenesis, and spermatozoa are found in the collecting tubules of most animals. The sperm ducts of most control animals have an actively secreting epithelial cell layer, and androgenic gland volume is at its maximum. Experimental animals exhibit similar histological features, with few exceptions. Spermatozoa are found in the collecting tubules of some animals, and the sperm ducts of these animals contain secretory material. The testes of some uxperimental animals contain germ cells in less advanced stajes of spermatogenesis than those of the majority of controls. Qualitative differences in testes histology are difficult to asses, however, as spermatogenesis proceeds rapidly once primary spermatocytes are present in the testes. In paraffin sections, the sperm ducts of experimental and control animals appear similar and no differences in histology are observed. As in the spring, no behavioral differences are observed in control and experimental crayfish. 
Androgenic Gland Implantation

Two groups of female crayfish, 17 to $30 \mathrm{~mm}$ carapace length, received androgenic gland implants during the spring and late summer. Each female was implanted with a pair of androgenic glands, the full gland complement of a normal male. Animals were maintained for periods of up to 60 days. Mortality rates for operated females were lower than for experimental males. Five percent of the operated females were lost due to the operative procedure or other causes during the course of the experimental period. As with the males, moulting in operated females was similar to that of controls.

The ovarian histology of both experimental and control females was similar. During both seasons, vitellogenic ova are present in the ovaries, and germ cells in earlier stages of development are also observed. Observations of ovarian tissue from numerous experimental females yielded no evidence of male germ cell development. Simple visual observation of paraffin sections revealed no major differences in the yolk storage of ova from experimental and control females of the same size. The oviducts of experimental and control females were similar in Doth seasonal groups.

During the spring, implanted gland tissue removed from female reclpients was observed to be similar to gland tissue from normal males. Vasses of gland tissue consisting of cellular strands were recovered from a number of experimental females. The implanted muscle tissue from control females also appeared normal when compared to muscle tissue from unoperated controls. In some females, however, the implanted sland tissue was invaded with granular hemolymph cells and tissue 
degeneration was apparent (Table III). Implanted gland tissue could rarely be identified in late summer experimental animals. When found, implanted tissue consisted of masses of cells with pycnotic nuclel, diffusely staining cytoplasm, and indistinct cell boundaries. This tissue was often surrounded by dense, brittle concretions, and contained numerous granular hemolymph cells. 


\section{PAJLE III}

A SUMMARY OF THE RESULTS OP ANDROGENIC GLAID RENOVAL AND IPPLANTATION IN ?. EENIUSCULUS.

\begin{tabular}{|c|c|c|}
\hline & & ANDROGENIC GLAND REMOVAL \\
\hline & Time of Year & Gland Histology \\
\hline $\begin{array}{l}\text { Vontrol Males } \\
18-40 \mathrm{~mm} \mathrm{c.1.4}\end{array}$ & Spring & $\begin{array}{lll}\text { Proliferation. Divid- } & \text { Increasing } & \text { No secretory ac- } \\
\text { ing, vacuolated, and } & \text { spermatogenic } & \text { tivity. Eplthe- } \\
\text { degenerating cells. } & \text { activity. } & \text { lial cell division. }\end{array}$ \\
\hline $\begin{array}{l}\text { Experimental Males } \\
18-40 \mathrm{~mm} \mathrm{c} .1\end{array}$ & Spring & $\begin{array}{l}\text { Same as Same as above. } \\
\text { above. }\end{array}$ \\
\hline $\begin{array}{l}\text { Control Males } \\
18-40 \mathrm{~mm} \mathrm{c.1}\end{array}$ & $\begin{array}{l}\text { Late } \\
\text { Summer }\end{array}$ & $\begin{array}{ll}\text { Spermatogene- } & \text { Secretion of mu- } \\
\text { sis near } & \text { cous-like material } \\
\text { completion. } & \text { occurring. }\end{array}$ \\
\hline $\begin{array}{l}\text { Experimental Males } \\
18-40 \mathrm{~mm} \mathrm{c} .1\end{array}$ & $\begin{array}{l}\text { Late } \\
\text { Summer }\end{array}$ & $\begin{array}{l}\text { Same as } \\
\text { above. }\end{array}$ \\
\hline & & ANDROGENIC GLAND IMPLANTATION \\
\hline & Time of Year & Ovarian Histology \\
\hline $\begin{array}{l}\text { Control Females } \\
17-30 \mathrm{~mm} \mathrm{c.1}\end{array}$ & Spring & $\begin{array}{l}\text { V1tellogenic and de- } \\
\text { reloping ova present. }\end{array}$ \\
\hline $\begin{array}{l}\text { Experimental Females } \\
17-30 \mathrm{~mm} \mathrm{c} .1\end{array}$ & Spring & $\begin{array}{l}\text { No differences in pleo- } \\
\text { pod morphology or be- } \\
\text { havior after moulting. }\end{array}$ \\
\hline $\begin{array}{l}\text { Control Females } \\
17-30 \mathrm{~mm} \mathrm{c.l} \text {. }\end{array}$ & $\begin{array}{l}\text { Late. } \\
\text { Summer }\end{array}$ & $\begin{array}{l}\text { Vitellogenic and de- } \\
\text { veloping ova present. }\end{array}$ \\
\hline $\begin{array}{l}\text { Experimental Females } \\
17-30 \mathrm{~mm} \mathrm{c.1}\end{array}$ & $\begin{array}{l}\text { Late } \\
\text { Sumner }\end{array}$ & $\begin{array}{l}\text { Some evidence of an } \\
\text { immune response to im- } \\
\text { planted tissue. }\end{array}$ \\
\hline * Carapace Length & & \\
\hline
\end{tabular}




\section{DISCUSSION}

As stated in the introduction, the malacostracan androgenic glands are thought to be the source of a hormone that maintains the form and sexual capability of male antmals. Speciflc knowledge of the endocrine function of these glands has come from studies involving the removal and implantation of gland tissue, and also from studies correlating gland structure with male reproductive activity (Adiyodi and Adiyod, 1970).

Removal of the glands of sexually mature $\underline{P}$. leniusculus, during both proliferative and degenerative phases of gland development, resulted with little, if any, information concerning their endocrine function (Table III). Since androgenic gland removal has been shown to cause a decrease in germ cell division and a cessation of spermatogenic activity in some amphipod and decapod species (Charniaux-Cotton, 1955; Puckett, 1964), the possibility exists that gland removal in $P_{\text {. }}$ leniusculus was incomplete or was carried out during post critical periods of the reproductive cycle.

Although a number of gland implants were maintained successfully in female recipients, no effects on ovarian histology or female secondary sex characters were noted (Table III). Previous studies of decapod glands; using implantation techniques, have shown that implanted glands are capable of inhibiting vitellogenesis, and also of having a masculinfing effect on female recipients (Payen, 1969; and others). Puckett, however, noted no changes in the ovaries or secondary sex 
characters of female crayfish which received implants of both testes and androgenic glands (Puckett, 1964). Since female P. lenfusculus were implanted with two glands, the full male complement, the lack of observable results could be due to an insufficient quantity of actively secreting gland tissue, or to implants of tissue in a nonsecretory phase. The experimental results are further complicated by the possibility of an immune response to the implanted gland tissue. Implanted gland tissue was often invaded with granular hemolymph cells and surrounded by layers of dense brittle material, especially in females nearing maturity. In addition, it is possible that tissue differentiation, in the experimental females, had proceeded beyond the stage of being capable to respond to the masculinizing, androgenic hormone. Although experimental studies of the androgenic glands of $\underline{P}$. leniusculus yielded little information concerning gland function, the tissue and cell structure of the glands is indicative of a yearly pattern of activity and secretion. A comparison of androgenic gland tis-. sue and cell structure with reproductive morphology and activity gives the following information (Table I). Proliferation of androgenic gland tissue occurs during early premoult phases of the moult cycle. This increase in gland size, through mitosis and cell growth, coincides with an increase in mitotic activity in the testes. As proliferation continues, strands of cells of varying structure can be identifled. These include; strands of dividing cells, vacuolated cells, and cells in various stages of degeneration. At the time of the yearly moult of mature animals, the androgenic glands contain numerous strands of cells with highly vacuolated cytoplasm, and spermatogenesis is occurring in the 
testes. Following ecdysis, spermatogenesis proceeds rapidly, and spermatozoa are present in the sperm ducts within a short period of time. The glands are at their maximum volume at this time, and consist primarily of strands of hypertrophied and degenerating cells. Degeneration of a major portion of the glands occurs prior to copulation, in the fall of the year. In the post-reproductive period following copulation, the glands are composed of a small number of cellular strands located in the muscle and connective tissue of the sperm ducts. At this time tine testes are depleted of germ cells and are in a disorgantzed, nonfunctional state.

During the proliferative phase of gland development, in late premoult $\underline{P}$. leniusculus, structural diversity among neighboring strands of cells is at a maxdmum. This condition, which indicates asynchronous cellular development, occurs in the glands of a number of decapod species (Charniaux-Cotton et al., 1966; Carpenter and deRoos, 1970; Payen, 1972; and others), and has been cited as evidence of the secretory nature of these glands (King, 1964a). In addition, the presence of degenerating cells in non-localized regions of supposedly functional glands has been considered by some to indicate a holocrine secretory process (Charniaux-Cotton, 1960; Tcholakian and Reichard, 1964; and others). Holocrine secretion, however, has not been confirmed by histochemical or ultrastructural studies (King, 1964a; Hoffman, 1969; and Payen, 1972).

Since gland proliferation in $\underline{P}$. leniusculus coincldes with the initiation of spermatogenesis in the testes, it seems likely that maximum secretory activity occurs at this time. The ultrastructure of a 
majority of non-dividing cells, especially the vacuolated cells, would seem to substantiate tins hypothesis. Cells undergoing vacuolization contain numerous mitochondria and a large amount of sac-like agranular endoplasmic reticulum. The nuclei of these cells are irregular in shape, highly indented at the periphery, and nucleoli are regularly observed. Vacuoles, both lacking membranes and membrane bound, are often closely associated with mitochondria, or are surrounded by endoplasmic reticulum. In some cells, lamellar arrangements of electron dense agranular membranes are in close proximity to large vacuoles, indicating a high amount of metabolic or synthetic activity. Vacuolated cells are most often encountered during gland proliferation, and are observed with much less frequency in other seasons of the year. Structurally similar cells have been described in the glands of a number of malacostracan species (Charniaux-Cotton et al., 1966; Hoffman, 1y69; and Carpenter and deRoos, 1970), and have previously been observed in the glands of Pacifastacus (King, 1964b). Cells of this type are common in the glands of the crayfish, Orconectes nais, at the time of the moult from the sexually inactive form to the active sexual form (varpenter and deRoos, 1970).

The cellular fine structure of various malacostracan glands has been reported to be similar to that of known protein synthesizing and secreting cells (King, 1964a; Meusy, 1965; and Malo and Juchault, 1y(0). However, certain features of protein secreting cells are lackin $n_{g}$ in the gland cells of $\underline{P}$. leniusculus. Electron dense Golgi bodies and vesicles, and membrane bound protein or polypeptide granules are not present in the cytoplasm of gland cells during active phases of 
development, both of which are characterlstics of known protein secreting cells (King, 1964a). Furthermore, granular endoplasmic reticulum, which is a diagnostic Seature of protein synthesizing cells, is never abundant in the gland cells of $\underline{P}$. leniusculus.

Although androgenic gland cells do not resemble known vertebrate steroid secreting cells, certain features of the glands are simflar to those of arthropod endocrine glands thought to be involved in the s:mthesis and release of lipid hormones. The insect prothoracic glands and the crustacean $Y$ organs, which are thought to be the source of steroid moulting hormones, and the insect corpora allata, which are the source of the lipid Juvenile Hormone, have been observed to undergo cyclic changes in cellular structure that can be correlated with hormonal activity. Increased secretory activity in all of these glands corresponas with an increase in cytoplasmic vacuolization, nuclear irregularity, and an increase in the number of organelles such as mitochondria (Gabe, 1953; Waku and Gilbert, 1964; Scharrer, 1964; and Herman, 1967). Simflar processes are observed in the glands of $\underline{p}$. leniusculus, especially during the proliferative phase in late spring. This suggests not only a similarity of the secretory processes, out also that the androgenic gland hormone is lipid in nature.

Although the vacuolar contents of the gland cells of $P$. leniuscuius were not identified, lipid vacuoles have been described in the hypertrophied glands of the crabs; Carcinus maenas, Callinectes sapidus, and Rithropanopeus narrisii (Meusy, 1965; Payen et al., 1971). Further evidence of the lipid nature of the androgenic gland hornone. has recently been reported (Berreur-Bonnenfant et al., 1973). These 
workers have extracted and partially purified a biologically active factor from the androgenic glands and hemolymph of the crab, Carcinus maenas. The active factor, which is in the lipid fraction of the extract, is capable of inhibiting vitellogenesis in the ovaries of Orchestia.

Thomsen and Thomsen, 1970, have suggested a working hypothesis for the synthesis and release of the lipid Juvenile Hormone, and it is possible that these processes occur in the same manner in the androgenic glands of $\underline{P}$. leniusculus. These authors hypothesize that the Juvenile Hormone is synthesized in the agranular endoplasmic reticulum and collected in membrane bound vacuoles. They also suggest that dissolution of the vacuolar membranes will result in the formation of lipid droplets in the cytoplasm, which subsequently will be released to intercellular spaces and the hemolymph (Thomsen and Thomsen, 1970). The androgenic glands are similar, in that vacuolization occurs in cells with large amounts of agranular endoplasmic reticulum and numerous ritochondria. Furthermore, cellular vacuolization is at a maximum when spermatogenesis is occurring in the testes, a time at which the androgenic hormone titer would be expected to be high. 


\section{BIBLIOGRAPHY}

Adiyodi, K. G. and R. G. Adiyodi. 1970. Endocrine control of reproduction in decapod crustacea. Biol. Rev. 45:121-166.

Berreur-Bonnenfant, J., et al. 1973. Recherches sur la secretion de la glande androgene des Crustaces Malacostraces: purification d'une substance a activite androgene. C. R. Acad. Sci., Paris, Ser. D. 277:971-974.

Carpenter, M. B. and R. deRoos. 1970. Seasonal morphology and histology of the androgenic gland of the crayflsh Orconectes nals. Gen. Somp. Endocrinol. 15:143-157.

Charniaux-Cotton, H. 1954. Decouverte chez un Crustace Amphipode (Orchestia gammarella) d'une glande endocrine responsable de la differenciation de characteres sexuels primaires et secondaires males. C. R. Acad. Sci., Paris, Ser. D. 239:780-782.

Tharnfaux-Cotton, $H$. 1955. Le determintsme hormonal des characteres sexuels d' Orchestia gammarella (Crustace Amphipode). C. R. Acad. Sci., Paris, Ser. D. 240:1487-1489.

Charniaux-Cotton, H. 1959. Masculinization des femelles de la Crevette a hermaphrodisme proteranderique Lysmata seticaudata, par greffe de glandes androgenes. Interpretation de I'hermaphrodisme chez les Decapodes. Note preliminatre. C. R. Acad. Sci., Paris, Ser. D. 249:1580-1582.

Charniaux-Cotton, H. 1960. Sex determination. (In) The Physiology of Crustacea, T. H. Waterman (Ed). V. 1. pp. 4ll-4h8. Academic Press, New York.

Charniaux-Cotton, H. 1962. Androgenic gland of crustaceans. Gen. Comp. Endocrinol. Suppl. 1. 24l-247.

Charniaux-Cotton, H. and L. H. Kleinholz. 1964. Hormones in invertebrates other than insects. (In) The Hormones, G. Pincus, K. V. Thimann, and E. B. Astwood (Eds). V. 4. pp. 135-198. Academic Press, New York.

Charniaux-Cotton, H. 1965. Controle endocrinien de la differenciation sexuelle chez les crustaces superieurs. Arch. Anat. Milcrosc. Morphol. Exp. 54:405-415. 
Charniaux-Cotton, H., C. Zerbib, and J. J. Meusy. 1966. Monographie de 1 a glande androgene des crustaces superiours. Crustaceana. $10: 113-136$.

Gabe, M. 1953. Sur l'existence chez quelques Crustaces Malacostraces, d'un organe comparable a' la glande de la mue des Insectes. C. R. Acad. Sc1., Paris, Ser. D. 237:1111-1113.

Graf, F. 1962. Intersexualitie et glande androgene chez Orconectes limosus (Rafinesque). I. Presence d'un pleopode de type malo chez une femelle. Crustaceana. 4:151-157.

Herman, W. S. 1967. The ecdysial glands of arthropods. Int. Rev. Cytol. 22:269-347.

Hobbs, H. H. 1974. Synopsis of the familles and genera of crayfishes (Crustacea:Decapoda). Smithsonian Contributions to Zoology. No. 164 .

Foffman, D. L. 1969. The development of the androgente glands of a protandric shrimp. Biol. Bull. 137:286-296.

Katakura, 1. 1967. Hormonal control of sex differentiation in the terrestrial isopod, Armadilitidun vulgare. Gunma Symp. Endocrinol. 4:49-64.

King, D. S. 196/4a. Fine structure of the androgentc gland of the crab, Pachygrapsus crassipes. Gen. Comp. Endocrinol. 4:533-544.

King, D. S. 1964b. Comparative morphology of the crustacean androgentc gland. M. A. Dissertation. Department of Zoology, University of California, Berkeley.

Luft, J. 1961. Improvements in epoxy resin embedding methods. J. Biophys. Biochem. Cytol. 9:409-4l4.

Malo, N. 1970. Premiers observations ultrastructurales de la glande androgene d' Onfscus asellus, Crustace Isopode, et ses modifications en fonction de la temperature d'olevage. C. R. Acad. Sci., Paris, Ser. D. 270:2843-2845.

Malo, N. and P. Juchault. 1970. Contribution a $I^{\prime}$ etude des varlations ultrastructurales de la glande androgene des Oniscoldes superieurs (Crustaces Isopodes), a la suite de la decerebration. C. R. Acad. Sci., Paris, Ser. D. 271:230-232.

Mason, J. C. 1963. If fe history and production of the crayfish, Pacifastacus leniusculus trowbridgil (Stimpson), in a small woodIand atreem. Masters thesis. Oregon State University, Corvallis. 
Payen, G. 1968. Experience de greffes de glandes androgenes sur le Crabe Carcinus maenus L. Premiers resultats. C. R. Acad. Sci., Paris, Ser. D. 266:1056-1058.

Payen, G. 1969. Experiences de greffes de glandes androgenes chez la femelle pubere du crabe Rithropanopeus harrisii (Gould) (Crustace Decapode). C. R. Acad. Sc1., Paris, Ser. D. 268:393-396.

Payen, G. 1970. Etude ultrastructurale des glandes androgenes hypertrophices a la suite de l' ablation des pedoncles oculaires su premier stade larvaire chez le crabe Rithropanopeus harrisil (Gould). C. R. Acad. Sci., Paris, Ser. D. 270:1499-1502.

Payen, G. 1972. Etude ultrastructurale de la degenerescence cellulaire dans la glande androgene du crabe Ocypode quadrata (Fabricius). Z. Zellforsch. 129:370-385.

Payen, G., J. D. Costlow, and H. Charniaux-Cotton. 1971. Etude comparative de l'ultrastructure des glandes androgenes de Crabes normaux et pedonculectomises pendant la vie larvaire ou apres la puberte chez les especes: Rithropanopeus harrisii (Gould) et Callinectes sapidus (Rathbun). Gen. Comp. Endocrinol. I7:526-542.

Puckett, D. H. 1964. Experimental studies on the crayfish androgenic gland in relation to testicular function. Doctoral Dissertation. Department of Zoology, University of Virginia.

Richardson, K. C., et al. 1960. Embedding in epoxy resins for ultrathin sectioni $\overline{n g} \overline{i n}$ electron mlcroscopy. Stain Technol. 35:313.

Scharrer, B. 1964. Histophysiological studies on the Corpus Allatum of Leucophae maderae. IV. Ultrastructure during normal activity cycie. Z. ZeIIforsch. $62: 125-148$

Tcholakian, R. K. and S. M. Relchard. 1964. A possible androgenic gland in Callinectes sapidus (Rathbun). Amer. Zoologist (Abstract). 4:383.

Thomsen, E. and M. Thomsen. 1970. Fine structure of the Corpus Allatum of the female blow-fly Calliphora erythrocephala. Z. Zellforsch.

van Harreveld, A. 1936. A physiological solution for freshwater crustaceans. Proc. Soc. Exp. Biol. and Med. 34:428-432.

Naku, Y. and L. I. Gilbert. 1964. The Corpora Allata of the silkmoth, Hyalophora cercropia: An ultrastructural study. J. Morphol. 
Zerbib, c: 1967. Premiere observation de la glande androgene chez un Crustace Syncaride: Anaspides tasmaniae (Thomsen) et chez un Crustace Eucarida: Meganyctiphanes norvegica (Sars). C. R. Acad. Sci., Paris, Ser. D. 265:415-418. 